\title{
ПРОБЛЕМИ І ПОТЕНЦІЙНІ МОЖЛИВОСТІ РЕАЛІЗУВАННЯ ІННОВАЦІЙНИХ СТРАТЕГІЙ ДЛЯ ПІДВИЩЕННЯ РІВНЯ КОНКУРЕНТОСПРОМОЖНОСТІ ПІДПРИЕМСТВА
}

\section{PROBLEMS AND POTENTIAL OPPORTUNITIES FOR IMPLEMENTATION OF INNOVATIVE STRATEGIES TO INCREASE THE COMPETITIVENESS OF THE ENTERPRISE}

\author{
Завербний Андрій Степанович \\ доктор економічних наук, профресор, \\ Національний університет «Львівська політехніка» \\ ORCID: https://orcid.org/0000-0001-7307-536X \\ Макарова Юлія Сергіївна \\ студентка, \\ Національний університет «Львівська політехніка» \\ ORCID: https://orcid.org/0000-0003-0287-031X
}

\author{
Zaverbnyj Andrij, Makarova Yuliia \\ Lviv Polytechnic National University
}

\begin{abstract}
У сучасному висококонкурентному середовищі метою кожної організації є підвищення конкурентоспроможності та залучення нових клієнтів. Завдяки творчості окремих осіб, їх знанням, навичкам, досвіду та вмінням можна генерувати нові інноваційні ідеї, які допоможуть підприємствам досягти конкурентних переваг. Метою статті $€$ представлення результатів аналізу інноваційних стратегій, які використовують провідні компанії світу для досягнення максимального рівня конкурентоспроможності у своїй галузі; аналіз інноваційних розробок, які можна використовувати вітчизняним підприємствам за умови нестабільності ситуації у зв'язку 3 COVID-19. Для українських підприємств це можливість досягти рівня компаній-гігантів, так як пандемія стала викликом для багатьох галузей та підприємств, а ті хто залишився на плаву та зміг адаптуватися, зможуть досягти у майбутньому максимального рівня конкурентних переваг. На основі Діаманту Конкурентоспроможності Портера було визначено основні напрямки для підвищення конкурентоспроможності та детально описано інновації на кожному етапі. Одним із висновків статті $€$ те, що організації вважають важливим впроваджувати інновації та підтримувати інноваційну культуру.
\end{abstract}

Ключові слова: конкурентні переваги, конкурентоспроможність, інновації, штучний інтелект, автоматизація виробництва.

В современной высококонкурентной среде целью каждой организации является повышение конкурентоспособности и привлечение новых клиентов. Благодаря творчеству отдельных лиц, их знаниям, навыкам, опыту и умениям можно генерировать новые инновационные идеи, которые помогут предприятиям достичь конкурентных преимуществ. Целью статьи является представление результатов анализа инновационных стратегий, используемых ведущими компаниями мира для достижения максимального уровня конкурентоспособности в своей отрасли; анализ инновационных разработок, которые можно использовать отечественным предприятиям при нестабильности ситуации в связи с COVID-19. Для украинских предприятий это возможность достичь уровня компаний-гигантов, так как пандемия стала вызовом для многих отраслей и предприятий, а оставшиеся на плаву и смогши адаптироваться смогут достичь в будущем максимального уровня конкурентных преимуществ. На основе Бриллианта Конкурентоспособности Портера были определены основные направления повышения конкурентоспособности и подробно описаны инновации на каждом этапе. Одним из выводов статьи есть то, что организации считают важным внедрять инновации и поддерживать инновационную культуру.

Ключевые слова: конкурентные преимущества, конкурентоспособность, инновации, искусственный интеллект, автоматизация производства. 
In today's environment, the goal of every organization is to increase competitiveness and attract new customers. Thanks to the creativity of individuals, their knowledge, skills, experience and skills, it is possible to implement new innovative ideas that will help companies achieve competitive advantage. The aim of the article is to present the results of the analysis of innovation strategies used by the world's leading companies to achieve the maximum level of competitiveness in their field; analysis of innovative developments that can be used by domestic enterprises in the event of instability in connection with COVID-19. For Ukrainian companies, this is an opportunity to reach the level of giant companies, as the pandemic has become a challenge for many industries and enterprises, and those who stayed afloat and were able to adapt will be able to achieve the maximum level of competitive advantage in the future. Based on the Porter Competitiveness Diamond (Factors of Production; Company Strategy; Demand Parameters; Related and Supporting Industries), the main directions for increasing competitiveness were identified and innovations at each stage were described in detail. In total, three main areas were identified - improving the technical level and quality of products; reduction of production costs and automation of the budgeting system; innovative strategies for service, advertising and market research. The level of Ukraine in the use of artificial intelligence by enterprises and the difference in profits between ordinary companies and those using the Al industry were determined. These strategies indicate that the automation of enterprise management systems is an integral part of the future competitive advantages of enterprises. The next innovative development is market research using biometrics. Biometrics uses: functional magnetic resonance imaging - scans and measures the consumer's brain to understand which product or service suits them best; face coding webcam - decodes the main emotions of the participants with the help of their facial expressions; electrocardiograph - monitors the heart rate of consumers and helps marketers monitor the reaction to the emotional backpack. One of the conclusions of the article is that organizations consider it important to implement innovations and maintain an innovation culture.

Keywords: competitive advantages, competitiveness, innovation, artificial intelligence, production automation.

Постановка проблеми. Конкурентні ринки продукції характеризуються націленістю на повне задоволення потреб споживачів, гнучкістю фрормування ринкової ціни, вільним входом і виходом з ринку, чесною торгівлею та діловими практиками. Найвищі цінності для компаній, що працюють на конкурентних ринках - це споживачі і потреби споживачів. Відповідно, всі рішення, пов'язані 3 діяльністю компаній, приймаються не виходячи з амбіцій підприємців, а з точки зору споживача як джерела майбутніх доходів і прибутків. Інновації $€$ одним із засобів забезпечення конкурентного шляху розвитку. Використовуючи досвід іноземних фрахівців, проблема постає в тому, які інноваційні напрямки та ідеї українські підприємства можуть впроваджувати.

Аналіз останніх досліджень і публікацій. Проблематику інноваційних стратегій та розробок для підвищення рівня конкурентоспроможності досліджували такі науковці, як П. Хонг [1], І. Дашко [2], Н. Богацька, А. Вітковська, В. Крупська [3], О. Малик, А. Хачатрян [4], В. Охота [5], М. Шульга [6], О. Каламан [7], Ю. Терлецька, Ю. Бачинська, В. Марчук [8], Л. Дубицька, Т. Примак [9], О. Дзеніс [10], О. Яременко, Г. Чечоткіна [11], В. Бугай, В. Сидоренко [12], О. Михайленко, К. Орлова [13], М. Палмер [14], С. Зоря [15].

Виділення невирішених раніше частин загальної проблеми. Актуальність впровадження штучного інтелекту в Україні для підвищення рівня конкурентоспроможності та потенційні можливості для українських підприємств піднятися на рівень провідних ком- паній світу; можливі позитивні та негативні наслідки використання розробок галузі.

Формулювання цілей статті (постановка завдання). Основними завданнями $\epsilon$ дослідження впливу інноваційних процесів на підвищення рівня конкурентоспроможності, визначення шляхів впливу на підвищення рівня конкурентоспроможності підприємства, аналізування інновацій іноземних підприємств, які можливо адаптовувати і використовувати на українських підприємствах з метою підвищення рівня їх конкурентоспроможності на вітчизняному та закордонному ринку; встановлення впливу штучного інтелекту на ситуацію на ринку та можливість використовувати розробки галузі для підприємств.

Виклад основного матеріалу дослідження. Багато фракторів впливають на конкурентоспроможність (ії рівень) на внутрішньому та міжнародному ринках. Цілісне уявлення про конкурентоспроможність підприємства доцільно відобразити у вигляді такого визначення: «конкурентоспроможність - це продемонстрована здатність розробляти, виготовляти та комерціалізувати пропозицію, яка повністю, унікально й постійно задовольняє потреби цільових сегментів ринку, підключаючись до бізнес-середовища та залучаючи ресурси 3 нього» [16].

Основними складовими конкурентоспроможності:

1. Конкуренція: здатність відповідати очікуванням ринку.

2. Зв'язок (комунікації): спілкування 3 іншими суб'єктами ринку, отримання інфор- 
мації про те, що відбувається на ринку і що потрібно.

3. Інновації: використання цієї інсрормації для передбачення ринкових тенденцій та адаптування до них.

Компанії країни повинні постійно підвищувати продуктивність у поточних секторах, покращуючи якість продукції, додаючи до продукції різні характеристики, розробляючи технологію продукту або посилюючи виробничу діяльність.

Чотири основні атрибути, що лежать в основі здатності компаній деяких країн розробляти інновації, обговорюються в Diamond Model of Porter (див. рис. 1). Цими детермінантами $€$ : параметри фракторів виробництва, стратегія (стратегії) підприємства, параметри попиту, споріднені та підтримуючі галузі [17].

Кожна точка діамантової моделі впливає на доступність ресурсів і талантів, необхідних для конкурентної переваги, а також тиск інвестицій та інновацій на інформацію, які $є$ основними елементами досягнення міжнародної конкуренції. Будь-яка галузь може бути успішною, якщо вона має сприятливі умови в середовищі, де вона працює.

Виходячи із вищевказаної інфрормації можемо навести основні напрямки, які може включати система забезпечення високої конкурентоспроможності:

1) інноваційні шляхи підвищення технічного рівня та рівня якості продукції (послуг), які у свою чергу включають:
- інноваційні методи навчання співробітників та підвищення рівня їх квалісікації,

- покращення умов праці,

- соціальний розвиток,

- удосконалення організації НДДКР,

- підвищення рівня ефрективності капіталовкладень

- удосконалення інвестиційної політики,

- стандартизування.

2) заходи, спрямовані на зниження витрат у процесі виробництва та вдосконалення системи бюджетування

3) заходи, які спрямовані на вдосконалення сервісного обслуговування, реклами, аналізування та вивчення ринків збуту.

Наступним кроком доцільно охарактеризувати кожен із основних напрямків та навести приклади інноваційних стратегій та розробок.

1.1. Розвиток та навчання персоналу підприємств. Фактично 23\% співробітників залишають компанії через погані можливості розвитку та навчання [18]. L'Oréal розробила перший у світі додаток для адаптації співробітників. Застосовуючи та навчаючи нових співробітників, щоб вони краще розуміли, розшифровували та оволоділи культурою своєї компанії, програма охоплює 10000 нових працівників щороку та доступна 11 мовами [18]. Однак, потрібно зазначити, що не кожне креативне рішення для навчання персоналу підприємства ідеально підходитиме. Деякі новації, методи повністю підходитимуть для

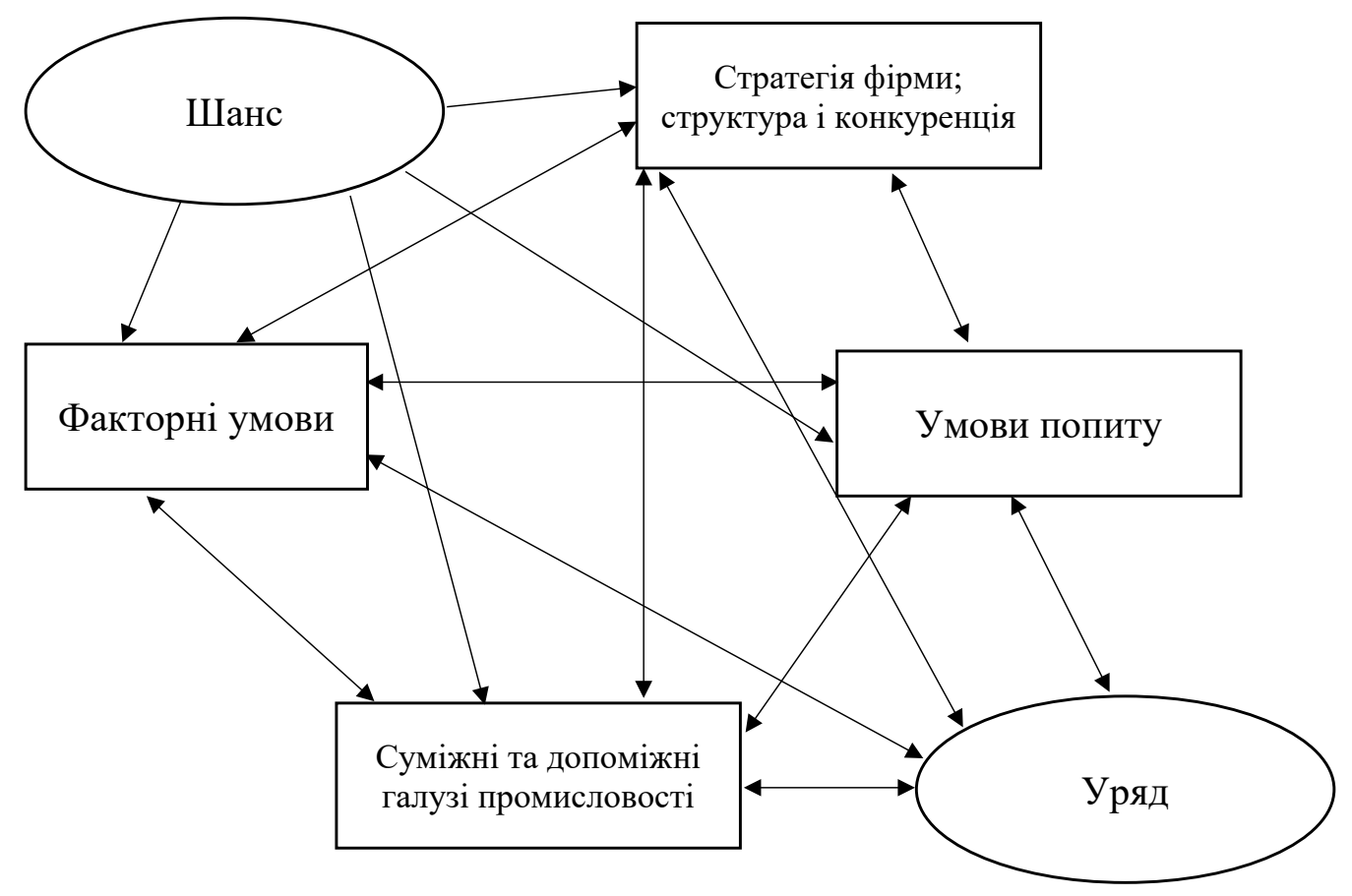

Рис. 1. Діамант конкурентоспроможності

Джерело: [17] 
бази співробітників, а інші - ні. Проаналізуємо основні із них.

Геймісрікація (ігри для навчання, що поєднують елементи веселощів із навчальним дизайном, щоб створити навчальну платформу, яка буде утримувати увагу співробітника та мотивувати його фрактично закінчити курс). Гейміфрікація в процесі навчання співробітників підприємства дозволятиме новим працівникам робити помилки, знаходити їх оптимальні рішення, формуючи стратегії без тиску на процес та виконання їх безпосередньої роботи. Приміром, процес адаптування нових співробітників L'Oréal заохочував їх виконувати завдання в реальному житті, але лишень після достатнього практикування в їх додатку. Також потрібно застерегти, що гейміфрікація не підходить до кожної ситуації чи навчального набору. Адже іноді доводиться дозволяти співробітникам вибирати, чому і як вони навчаються. Тому залучення відгуків співробітників виступає наступною інноваційною технікою, яку кожне підприємство повинне вводити задля оптимального процесу адаптування, навчання.

Зворотній зв'язок. Незалежно від того, чи залучують співробітників за допомогою онлайн-курсів, групових проектів чи індивідуальних тренінгів, зворотний зв'язок $є$ важливим етапом кожного навчання персоналу. Приміром, фрінський гігант мобільних ігор Supercell, який маючи менше 300 співробітників, вони отримали дохід у 2,3 мільярда доларів у 2016 р. Формуючи корпоративну культуру, яка робить співробітників центром успіху та визначає пріоритетність взаємодії співробітників під час адаптування, Supercell створила власне плідне середовище зворотного зв'язку (це інструмент для продовження навчання через отримання інформації). Пропонування конструктивної критики в кризових моментах в процесі навчання співробітників зміцнюватиме, узгоджуватиме цілі підприємства, покращуватиме відносини тощо. Постійне навчання за допомогою зворотного зв'язку $€$ ключем до досвіду ваших співробітників і зростання вашої компанії.

Залучення успіху клієнта. Для компаній звичайна практика документувати історії успіху клієнтів у тематичні дослідження, щоб продавати свою продукцію майбутнім клієнтам. Але також можна використовувати ці історії успіху клієнтів як інноваційний метод навчання співробітників. Залучення успіху клієнтів під час процесу навчання співробітників дозволить поділитися досвідом клієнтів 3 новими співро- бітниками. Вони з перших рук отримають уявлення про поточні настрої клієнтів, включаючи сумніви, страхи, виклики та тріумсри.

Змішані методи навчання. Змішане навчання може забезпечити правильне поєднання відкритих онлайн-курсів, навчання під керівництвом інструкторів та гейміфікації для створення програм, які відповідають потребам співробітників. Надання співробітникам різних видів досвіду для навчання дозволяє відстежувати, які методи насправді призводять до кращої продуктивності.

Інтерактивні посібники із програмного забезпечення. Інтерактивні посібники - це новітня технологія, яка покращує роботу 3 людськими ресурсами та індустрію навчання працівників. Доведено, що вони підвищують залучення співробітників, збереження знань. Інтерактивні посібники розділені на розділи та накладаються безпосередньо на будь-який вид додатків. Таким чином, нових співробітників можна навчати автоматично за допомогою самого програмного забезпечення [18].

1.2. Покращення рівня якості продукції (послуг, робіт). Минулі роки вплинули на компанії, яким довелося впроваджувати інновації, щоб залишатися конкурентоспроможними, обслуговувати клієнтів і швидко керуватися зміною ситуації. Системи управління якістю (QMS) зарекомендували себе, допомагаючи забезпечити безпеку заводів, ефективність виробничих ліній і ланцюгів поставок, а також гарантувати бездесректну продукцію. QMS спокійно зайняла провідне місце як одна із основних систем під час COVID-19. Багато компаній звернулися до своєї QMS, щоб легше проводити дистанційні аудити, контролювати та керувати документами з будь-якого місця, співпрацювати та спілкуватися 3 партнерами ланцюга поставок, виявляти потенційні проблеми до того, як вони стали реальністю, та стандартизувати методи безпеки на підприємстві.

Розширена аналітика. Використання якісних даних для прогнозування (планування) майбутніх результатів, визначення тенденцій та постійного вдосконалення - це ключові переваги розширеної аналітики. Враховуючи величезну кількість даних, які збирає будь-яка QMS, важливо вивести ці дані на абсолютно новий рівень зручності використання. Розширена аналітика дає змогу глибше зрозуміти якість постачальників, виробничі процеси, скарги клієнтів та вирішення проблем. Покладаючись на історичну інсрормацію, виробники можуть виявляти попереджувальні сигнали та 
попереджати про них і краще планувати майбутні проблеми, які можуть вплинути на бізнес.

Поглиблене інтегрування підприємства. Оскільки корпоративні технологічні стеки продовжують поглиблюватися, а автоматизація стимулює збільшення активності, QMS має бути достатньо гнучкою, щоб підключатися до багатьох інших програм для інтегрування корпоративної системи. Системи також повинні мати можливість інтегруватися із постачальниками для легшої та ефективнішої співпраці. Крім того, аналітика QMS має бути в змозі інтегруватися з інструментами Business Intelligence (BI) підприємства, щоб забезпечити двосторонній обмін даними та повне аналітичне уявлення щодо рівня якості, корпоративних даних тощо.

Автоматизоване управління безпекою. Одна річ, яка не зникне після COVID-19 - це зосередженість на здоров"ї та рівні безпеки робочих місць. Розширена QMS повинна допомогти проаналізувати, моніторити і визначити небезпеки на роботі до того, як вони виникнуть, встановивши правильні засоби контролювання. Також сприятиме збору даних щодо поведінки задля виявлення небезпечних методів, несправного обладнання, що можуть впливати на самопочуття співробітників, усувати дані ризики.

Якість на основі штучного інтелекту. Алгоритми штучного інтелекту будуть все більше вбудовуватися у QMS, щоб підвищити рівень якості результатів, робити прогнози, тестувати й навчатися автономно. Проте рівень якості даних буде визначати, наскільки точно працюватиме рішення штучного інтелекту. Cорормований на основі наявних якісних даних, поряд із даними всього підприємства, штучний інтелект може сортувати великі обсяги інформації, щоб приймати рішення або позначати потенційні проблеми. Можна очікувати, що штучний інтелект виведе QMS на новий рівень ефрективності та автоматизування [14].

2.1. Автоматизування системи бюджетування підприємств. Процес реалізування технології бюджетування на вітчизняних підприємствах-суб'єктах зовнішньоекономічної діяльності потребує суттєвих змін. Беручи до уваги досвід іноземних фрахівців, варто зазначити, що в межах закордонних компаній електронні таблиці (типу MS Excel) поступово втрачають свою ефективність, а отже й актуальність, а тому все частіше застосовуються автоматизовані інструменти фрінансового планування та аналізу, де процедури бюджетування - не виняток. Автоматизу- вати процес бюджетування можна за допомогою наступних програм: Google Sheets, SAP SEM (Strategic Enterprise Management) BPS (Business Planning and Simulation), 1C: Бюджетування, Active Planner, Neubrain, Vena Solutions, Prophix, Budget Maestro, IduConcept, NetSuite, Maxiplan, Tagetik та ін. Кожна програма має свої особливості застосування, які необхідно враховувати при застосуванні на підприємстві [19].

3.1. Головні інновації, які використовують найбільш інноваційні компанії світу для дослідження ринку. Ними є наступні.

Автоматизування. Інноваційні компанії тепер інтегрують збір та аналіз даних за допомогою програмного забезпечення для автоматизації маркетингових досліджень. За допомогою телефонних опитувань (САTI) та онлайнових опитувань фррагменти даних можна точно нарізати за лічені секунди. Далі вони обробляються, щоб зосередитися на відповідях клієнтів.

Штучний інтелект (Ш). В Україні налічується 57 компаній, які працюють у сорері Шا. Більше в регіоні тільки у Польщі (110) та Росії (133). Водночас в Україні всього 11 інвесторів галузі - це п'ятий показник. Україна входить до трійки країн Східної Європи за кількістю компаній у сорері штучного інтелекту (див. табл. 1) [20]. Про це свідчать дані звіту Artificial Intelligence Industry in Eastern Europe 2019, складеному компанією Deep Knowledge Analytics [20].

Ш для досліджень - це ще одне провідне програмне забезпечення для дослідження ринку, яке полегшує задачу залучення споживачів та розробки опитувань. Залучаючи зусилля штучного інтелекту, інноваційні компанії можуть отримати більше уявлень про свою цільову аудиторію. Важливими є аналізування тексту (виявляє, що відчуває аудиторія щодо нових тем бренду з точки зору інтенсивності та частоти) та машинне навчання (розкриває прогнозні моделі поведінки споживачів).

Біометрія - це нова тенденція в сучасному програмному забезпеченні для дослідження нейроринків. Більшість провідних інноваційних підприємств використовують різноманітні біометричні технології для розкриття когнітивних та емоційних реакцій споживачів на певний продукт/послугу. За допомогою біометричних систем дослідники ринку зможуть оцінювати те, що відбувається через підсвідомість їх учасників. Біометрія як правило використовує фрункціонально магнітно-резонансну томографрію (сканує та вимірює мозок 
споживача, щоб зрозуміти, який продукт чи послуга їм найкраще підходить), веб-камеру задля кодування обличчя: декодує основні емоції учасників за допомогою виразів їх обличчя, що допомагатиме зрозуміти, як вони ставляться до певного продукту чи послуги), електрокардіограсру (відстежує частоту серцевих скорочень споживачів і допомагає маркетологам спостерігати за реакцією на емоційний рюкзак, відстежуючи частоту серцевих скорочень, маркетологи можуть мати більш чітке уявлення про те, як споживач реагує на надані послуги) [15].

3.2. Найкращі стратегії онлайн-реклами. Викоремимо оптимальні з них.

Пошукове оптимізування. Веб-сайт може стати чудовим маркетинговим інструментом, але лише якщо потенційні клієнти зможуть його знайти. Найкращий спосіб зробити це - пошукова оптимізація або SEO. Інвестуючи в SEO можна покращити свій веб-сайт так, щоб він чітко розпізнавався пошуковими системами, такими як Google, для пошуку, пов'язаного із продуктами/послугами організації. SEO передбачає включення ключових слів, пов'язаних з продуктами/послугами на веб-сайті організації. Коли користувачі шукатимуть ці ключові слова в пошукових системах, у результатах відображатимуться релевантні сторінки.

Реклама із оплатою за клік (РPC). Плата за клік або РPС - це модель онлайн-реклами, яка дозволяє розміщувати оголошення в результатах пошукової системи за певними ключовими словами. У той час як SEO зосереджується на підвищенні рейтингу за допомогою вмісту та оптимізуванні, РРС дозволяє сплачувати за розміщення цільових ключових слів. РРС працює за системою ставок, у якій вибираються цільові ключові слова, а потім відбувається змагання з іншими рекламодавцями за розміщення оголошень у результатах пошуку за цими ключовими словами. Якщо ставка $€$ однією із найвищих, як результат підприємство отримає вище місце над результатами звичайного пошуку. Однією із найбільших переваг PPC € те, що плата відбувається лише тоді, коли користувачі натискають на рекламу.

Контент-маркетинг. Контент-маркетинг це чудовий спосіб опосередковано рекламувати бізнес споживачам, надаючи корисну чи цікаву інфрормацію. Можна створювати контент у вигляді блогів, відео, інфрограсріки та практично будь-якого онлайн-фрормату. Незалежно від галузі, публікація оригінального контенту $€$ надзвичайно ефрективним спосо-
Таблиця 1

Кількість компаній та інвесторів у галузі штучного інтелекту у 2019 р.

\begin{tabular}{|c|c|c|}
\hline Країни & $\begin{array}{c}\text { Кількість } \\
\text { компаній }\end{array}$ & $\begin{array}{c}\text { Кількість } \\
\text { інвесторів }\end{array}$ \\
\hline Вірменія & 12 & 10 \\
\hline Білорусь & 47 & 27 \\
\hline Естонія & 46 & 27 \\
\hline Грузія & 4 & 1 \\
\hline Казахстан & 4 & 2 \\
\hline Латвія & 26 & 11 \\
\hline Литва & 29 & 5 \\
\hline Польща & 110 & 59 \\
\hline Румунія & 32 & 1 \\
\hline Росія & 133 & 76 \\
\hline Україна & 57 & 11 \\
\hline
\end{tabular}

бом зв'язатися 3 цільовою аудиторією. Підприємства, які публікують 16 і більше разів на місяць, отримують у 4 рази більше трасріку, ніж компанії, які розміщують лише кілька разів на місяць. Це може здатися складним і тривалим зобов'язанням, але його можна полегшити, якщо співпрацювати з агентством, що надає послуги копірайтингу.

3.3. Інноваційні маркетингові стратегії передових іноземних компаній.

Продукти IKEA відомі рівнем деталізації, який вкладається в їхній дизайн - що дозволяє легко зібрати меблі, часто без інструментів, - і так само саме в деталях маркетингу IKEA компанія $€$ найбільш інноваційною. У 2013 році IKEA запустили додаток Catalog, який не тільки надав користувачам доступ до інвентарю компанії, але й за допомогою доповненої реальності фрактично дозволив їм побачити, як товари виглядатимуть у їхніх домах. У попередні роки IKEA представили платорорму, яка допомагала клієнтам продавати свої вживані меблі, навіть допомагаючи користувачам фоотографрувати та відкривати сторінку бренду у Facebook, щоб діяти як «онлайн-маркет» [1].

Virgin America працює в конкурентній галузі, де лояльність до бренду та обслуговування клієнтів є ключовими. Зворотний зв'язок відіграє вирішальну роль, тому Virgin представила програму фрокус-груп VX Next, групу 3 30 часто літаючих пасажирів і підприємців, які генерують ідеї для авіакомпанії в обмін на винагороду для пасажирів. Як прямий результат їхніх відгуків, Virgin America запровадила соціальну мережу в польоті, яка дозволяє пасажирам підключатися під час польоту [1]. 
Додаток Makeup Genius від L'Oréal дозволяв користувачам використовувати свої телефони, щоб зробити цифрровий макіяж. Бренд найняв ту саму команду, яка займалася створенням гри «Дивна справа Бенджаміна Баттона» для забезпечення необхідних реалістичних візуальних ефректів. Споживачі відгукнулися позитивно; додаток вже було завантажено понад 7 мільйонів разів. Бренд також проявив сміливість і в інших циоррових каналах, створивши унікальну лінію «Em-Cosmetics» для надзвичайно впливового блогера про макіяж Мішель Фан [1].

Висновки. Інновації дозволяють організаціям залишатися актуальними на конкурентному ринку, вони також відіграють важливу роль в економічному зростанні. Здатність вирішувати критичні проблеми залежить від інноваційної діяльності. Інноваційні методи зможуть допомагати будувати корпоративну культуру безперервного навчання, зростання та особистого розвитку. Такий тип інноваційного середовища може знову спонукати людей постійно вдосконалювати свою роботу та роботу в команді. У статті проаналізовані інноваційні стратегії за трьома основними напрямками збільшення рівня конкурентоспроможності підприємства, і багато уваги приділяють двом особливостям у зв'язку із нинішньою ситуацією на ринках - автоматизування всіх систем управління (менеджменту) підприємства та використання штучного інтелекту на всіх фразах випуску нової продукції. Досліджені та проаналізовані інноваційні стратегії можуть бути актуальними для однієї компанії та зовсім не підходити іншій; багато також залежатиме від галузі. Проаналізовані приклади одних із основних компаній на ринку різних галузей може наштовхнути на інноваційну стратегію українських підприємств.

\section{СПИСОК ВИКОРИСТАНИХ ДЖЕРЕЛ:}

1. Пет Хонг. 5 прикладів інноваційних маркетингових стратегій. URL: ttps://www.linkdex.com/en-gb/inked/ innovative-marketing-strategies-examples/\#comments (дата звернення: 20.01.2022).

2. Дашко І.М. Шляхи підвищення конкурентоспроможності промислових підприємств в ринкових умовах. Ефективна економіка. 2018. № 6. URL: http://www.economy.nayka.com.ua/?op=1\&z=7760

3. Богацька Н.М., Вітковська А.С., Крупська В.А Напрями підвищення конкурентоспроможності підприємств в сучасних умовах. Електронне видання ECONOMICS. URL: https://www.ukrlogos.in.ua/ 10.11232-2663-4139.15.24.html

4. Малик О.В., Хачатрян А.А. Шляхи підвищення конкурентоспроможності підприємств в ринкових умовах господарювання. URL: https://eprints.kname.edu.ua/45298/1/ilovepdf_com-85-87.pdf

5. Охота В.І. Шляхи підвищення конкурентоспроможності підприємств готельної індустрії. Інвестиції: практика та досвід. 2017. № 5. С. 46-49.

6. Шульга М. (Розроблення напрямів підвищення конкурентоспроможності підприємства. Підприємництво та інновації. 2020. № 12. С. 135-141. URL: https://doi.org/10.37320/2415-3583/12.23

7. Каламан О.Б. Шляхи підвищення конкурентоспроможності підприємств малого та середнього бізнесу виноробної галузі. Проблеми і перспективи економіки та управління. 2019. № 4(20). С. 426-441.

8. Терлецька Ю.О., Бачинська Ю.О., Марчук В.І. Шляхи підвищення конкурентоспроможності підприємств олійно-жирового комплексу в умовах невизначеності зовнішнього середовища. Економіка і суспільство. 2018. Випуск 14. С. 523-538.

9. Дубицька Л., Примак Т. Підвищення конкурентоспроможності підприємств сфери гостинності. Економіка та суспільство. 2021. № 23. DOI: https://doi.org/10.32782/2524-0072/2021-23-11

10. Дзеніс О.О. Вдосконалення стратегії підвищення міжнародної конкурентоспроможності підприємства. Економіка та управління підприємствами. 2018. Випуск 21. С. 266-272.

11. Яременко О., Чечоткіна Г. Методи оцінки та шляхи підвищення конкурентоспроможності підприємства. Науковий вісник МНУ імені В.О. Сухомлинського. Економічні науки. № 1(8), червень 2017. С. 55-61.

12. Бугай В.3., Сидоренко В.О. Основні напрями підвищення конкурентоспроможності підприємства. Modern Economics. 2019. № 14. С. 33-38. URL: https://doi.org/10.31521/modecon. V14(2019)-05

13. Михайленко О.В. Орлова К.Г. Система управління конкурентоспроможністю продукції підприємства. Науковий вісник Ужгородського національного університету. Серія : Міжнародні економічні відносини та світове господарство. 2017. Випуск 13(2). С. 114-117.

14. Морган Палмер. Використання нових технологій для забезпечення майбутнього вашої системи управління якістю. URL: https://www.qualitymag.com/articles/96661-leveraging-new-technologies-to-future-proof-yourquality-management-system 
15. Cофрі Зоря. Електронна платформа MEDIUM. Стратегії, які приймають більшість інноваційних компаній у галузі дослідження ринку, щоб досягти успіху. URL: https://medium.com/swlh/strategies-most-innovativecompanies-in-market-research-adopt-to-reach-success-cb7f0325cc9b

16. Local business intelligence - дослідження конкурентоспроможності. URL: https://www.intracen.org/smecs/ What-is-competitiveness/

17. Теорія конкурентних переваг М. Портера. URL: https://pidru4niki.com/12461220/ekonomika/teoriya_ konkurentnih_perevag_portera_porters_competitive_advantage_theory

18. Електронна платсорма Userlane. Інноваційні методи навчання для більшого утримання співробітників і зростання компанії. URL: https://www.userlane.com/5-innovative-employee-training-techniques-to-consider/

19. Макарова Ю.С., Чиркова Ю.Л. Сучасні аспекти застосування автоматизованих систем бюджетування підприємств-суб'єктів ЗЕД. Збірник тез доповідей 79-ї студентської науково-технічної консреренції. Львів : Видавництво Національного університету “Львівська політехніка", 2021.

20. Електронна платформа сьогодні (2019). Україна увійшла в ТОП-3 країн регіону за кількістю компаній у сорері штучного інтелекту. URL: https://economics.segodnya.ua/ua/economics/business/ukraina-voshla-v-top-3stran-regiona-po-kolichestvu-kompaniy-v-sfere-iskusstvennogo-intellekta-1220736.html

\section{REFERENCES:}

1. Pet Khonh (2021) 5 prykladiv innovatsiinykh marketynhovykh stratehii [5 examples of innovative marketing strategies]. Available at: ttps://www.linkdex.com/en-gb/inked/innovative-marketing-strategies-examples/\#comments (accessed 20 January 2022).

2. Dashko I.M. (2018) Shliakhy pidvyshchennia konkurentospromozhnosti promyslovykh pidpryiemstv v rynkovykh umovakh [Ways to increase the competitiveness of industrial enterprises in market conditions.]. Efektyvna ekonomika, no. 6. Available at: http://www.economy.nayka.com.ua/?op=1\&z=7760

3. Bohatska N.M., Vitkovska A.S., Krupska V.A (2020) Napriamy pidvyshchennia konkurentospromozhnosti pidpryiemstv $v$ suchasnykh umovakh [Directions for increasing the competitiveness of enterprises in modern conditions]. Elektronne vydannia ECONOMICS. Available at: https://www.ukrlogos.in.ua/10.11232-2663-4139.15.24.html

4. Malyk O.V., Khachatrian A.A. (2020) Shliakhy pidvyshchennia konkurentospromozhnosti pidpryiemstv v rynkovykh umovakh hospodariuvannia [Ways to increase the competitiveness of enterprises in market conditions]. Available at: https://eprints.kname.edu.ua/45298/1/ilovepdf_com-85-87.pdf

5. Okhota V.I. (2017) Shliakhy pidvyshchennia konkurentospromozhnosti pidpryiemstv hotelnoi industrii [Ways to increase the competitiveness of the hotel industry]. Investytsii: praktyka ta dosvid, no. 5, pp. 46-49.

6. Shulha M. (2020) Rozroblennia napriamiv pidvyshchennia konkurentospromozhnosti pidpryiemstva [Development of directions to increase the competitiveness of the enterprise]. Pidpryiemnytstvo ta innovatsii, no. 12, pp. 135-141. DOI: https://doi.org/10.37320/2415-3583/12.23

7. Kalaman O.B. (2019) Shliakhy pidvyshchennia konkurentospromozhnosti pidpryiemstv maloho ta serednoho biznesu vynorobnoi haluzi [Ways to increase the competitiveness of small and medium-sized businesses in the wine industry]. Problemy i perspektyvy ekonomiky ta upravlinnia, no. 4(20), pp. 426-441.

8. Terletska Yu.O., Bachynska Yu.O., Marchuk V.I. (2018) Shliakhy pidvyshchennia konkurentospromozhnosti pidpryiemstv oliino-zhyrovoho kompleksu v umovakh nevyznachenosti zovnishnoho seredovyshcha [Ways to increase the competitiveness of oil and fat enterprises in the uncertain environment]. Ekonomika i suspilstvo, no. 14, pp. 523-538.

9. Dubytska L., Prymak T. (2021) Pidvyshchennia konkurentospromozhnosti pidpryiemstv sfery hostynnosti [Improving the competitiveness of hospitality enterprises]. Ekonomika ta suspilstvo, no. 23. DOI: https://doi.org/ 10.32782/2524-0072/2021-23-11

10. Dzenis O.O. (2018) Vdoskonalennia stratehii pidvyshchennia mizhnarodnoi konkurentospromozhnosti pidpryiemstva [Improving the strategy of increasing the international competitiveness of the enterprise]. Ekonomika ta upravlinnia pidpryiemstvamy, no. 21, pp. 266-272.

11. Yaremenko O., Chechotkina H. (2017) Metody otsinky ta shliakhy pidvyshchennia konkurentospromozhnosti pidpryiemstva [Assessment methods and ways to increase the competitiveness of the enterprise]. Naukovyi visnyk MNU imeni V.O. Sukhomlynskoho. Ekonomichni nauky, no. 1(8), cherven 2017, pp. 55-61.

12. Buhai V.Z., Sydorenko V.O. (2019) Osnovni napriamy pidvyshchennia konkurentospromozhnosti pidpryiemstva [The main directions of increasing the competitiveness of the enterprise]. Modern Economics, no. 14, pp. 33-38. DOI: https://doi.org/10.31521/modecon.V14(2019)-05

13. Mykhailenko O.V., Orlova K.H. (2017) Systema upravlinnia konkurentospromozhnistiu produktsii pidpryiemstva [Enterprise product competitiveness management system]. Naukovyi visnyk Uzhhorodskoho natsionalnoho universytetu. Seriia: Mizhnarodni ekonomichni vidnosyny ta svitove hospodarstvo, no. 13(2), pp. 114-117. 
14. Morhan Palmer (2021) Vykorystannia novykh tekhnolohii dlia zabezpechennia maibutnoho vashoi systemy upravlinnia yakistiu [Use new technologies to secure the future of your quality management system]. Available at: https://www.qualitymag.com/articles/96661-leveraging-new-technologies-to-future-proof-your-quality-management-system

15. Sofi Zoria (2020) Elektronna platforma MEDIUM. Stratehii, yaki pryimaiut bilshist innovatsiinykh kompanii $\mathrm{u}$ haluzi doslidzhennia rynku, shchob dosiahty uspikhu [Strategies that most innovative companies adopt in market research to succeed]. Available at: https://medium.com/swlh/strategies-most-innovative-companies-in-marketresearch-adopt-to-reach-success-cb7f0325cc9b

16. Local business intelligence - doslidzhennia konkurentospromozhnosti [Local business intelligence - competitiveness study] (2021). Available at: https://www.intracen.org/smecs/What-is-competitiveness/

17. Teoriia konkurentnykh perevah M. Portera [M. Porter's theory of competitive advantage]. Available at: https://pidru4niki.com/12461220/ekonomika/teoriya_konkurentnih_perevag_portera_porters_competitive_advantage_theory

18. Elektronna platforma Userlane. Innovatsiini metody navchannia dlia bilshoho utrymannia spivrobitnykiv i zrostannia kompanii [Innovative training methods for greater employee retention and company growth]. Available at: https://www.userlane.com/5-innovative-employee-training-techniques-to-consider/

19. Makarova Yu.S., Chyrkova Yu.L. (2021) Suchasni aspekty zastosuvannia avtomatyzovanykh system biudzhetuvannia pidpryiemstv-subiektiv ZED. Zbirnyk tez dopovidei 79-yi studentskoi naukovo-tekhnichnoi konferentsii. Lviv: Vydavnytstvo Natsionalnoho universytetu "Lvivska politekhnika".

20. Elektronna platforma sohodni (2019) Ukraina uviishla v TOP-3 krain rehionu za kilkistiu kompanii u sferi shtuchnoho intelektu [Ukraine is in the TOP-3 countries in the region by the number of companies in the field of artificial intelligence]. Available at: https://economics.segodnya.ua/ua/economics/business/ukraina-voshla-v-top-3-stran-regiona-po-kolichestvu-kompaniy-v-sfere-iskusstvennogo-intellekta-1220736.html 